\title{
Epidemiological and Clinical Profile of Breast Cancer at Bamako Radiotherapy Center
}

\author{
A. S. Kone ${ }^{1 *}$, A. Diakite1, I. M. Diarra1, K. Diabate1, M. A. Camara², Y. L. Diallo³, S. Sidibe ${ }^{4}$ \\ ${ }^{1}$ Radiotherapy Center, Mali Hospital, Bamako, Mali \\ ${ }^{2}$ Radiology Department, Mali Hospital, Bamako, Mali \\ ${ }^{3}$ Department of Medicine and Endocrinology, Bamako Hospital, Bamako, Mali \\ ${ }^{4}$ Department of Radiology, Point G Hospital, Bamako, Mali \\ Email: *aphousalle@yahoo.fr
}

How to cite this paper: Kone, A.S., Diakite, A., Diarra, I.M., Diabate, K., Camara, M.A., Diallo, Y.L. and Sidibe, S. (2019) Epidemiological and Clinical Profile of Breast Cancer at Bamako Radiotherapy Center. Journal of Cancer Therapy, 10, 739-746.

https://doi.org/10.4236/jct.2019.109062

Received: July 2, 2019

Accepted: September 8, 2019

Published: September 11, 2019

Copyright (C) 2019 by author(s) and Scientific Research Publishing Inc. This work is licensed under the Creative Commons Attribution International License (CC BY 4.0).

http://creativecommons.org/licenses/by/4.0/

\begin{abstract}
Breast cancer is a major public health problem because of its incidence and mortality. Purpose: To establish the epidemiological and clinical characteristics of breast cancer seen at the radiotherapy center at the Mali Hospital of Bamako. Patients and methods: It was a retrospective, descriptive study of data from patients seen for breast cancer at the Center of Radiotherapy of Mali Hospital between April 2014 and December 2016. The parameters studied were: age, sex, family history of breast cancer, menopausal status, parity, breast tumor location, histological type, histological grade, cancer classification stage. Results: 134 cases of breast cancer were collected, with a frequency of $15 \%$. The sex ratio $(\mathrm{H} / \mathrm{F})$ of 0.007 . The patient's mean age was $47 \pm 11$ years old. The most represented age groups were 33 - 47 years old with $45.5 \%$ and 48 - 62 years old with $39 \%$. Three percent (3\%) of patients had a family history of breast cancer. Fifty (50\%) of the patients were menopausal. The main clinical signs found were : mammary nodules (98\%), mastodynia (65\%), nodes $(67 \%)$. Invasive ductal carcinomas were found in $94 \%$ of patients, followed by infiltrating lobular carcinomas with $3.7 \%$ and metaplastic carcinomas with $1.7 \%$. SBR Grades II and III were mostly found with $37 \%$ and $23 \%$. The average tumor size was $87 \mathrm{~mm} \pm 43$. Stage III was predominantly represented with $72 \%$, followed by Stage II with $24 \%$ and Stages I and IV with $2 \%$ each. Conclusion: Breast cancer is common and reaches both before and after 50 years; the diagnosis is usually late; hence it is the importance of raising awareness and screening before the age of 50 and popularizing some complementary tests to better understand the prognosis of this disease and promote more targeted and conservative treatments that will improve survival.
\end{abstract}

\section{Keywords}

Breast Cancer, Epidemiology, Clinic 


\section{Introduction}

Breast cancer is characterized by the uncontrolled development of cancer cells in the mammary gland. It is a major public health problem because of its high incidence and mortality. With 2.088.849 new cases identified (11.6\%) and $626.679(6.6 \%)$ cases of death worldwide, it accounts for $25.1 \%$ of all cancers [1] [2].

The incidence of breast cancer is 4 to 10 times higher in Western countries (mainly in the United States and Northern Europe) compared to Asia and Africa [1] [3].

In sub-Saharan Africa, the incidence of breast cancer varies by country [4]; in Mali, from 2006 to 2010 it is in second place after the cervix, with a relative frequency of $18.7 \%$, it is the second cause of cancer death after cervical cancer [5]. It is currently first cancer in terms of incidence according to the 2010-2017 Bamako cancer registry.

To our knowledge, in Mali, there are no published data on the epidemiological and clinical characteristics of this cancer. This is why, in this work, we propose to study the epidemiological and clinical characteristics of breast cancer treated at the radiotherapy center of the Mali Hospital of Bamako.

\section{Patients and Methods}

This was a retrospective and descriptive study of the data of patients monitored for breast cancer at the Bamako Radiotherapy Center of the Mali Hospital, between April 2014 to December 2016.

Included in the study was any case of histologically proven breast cancer and seen at the radiotherapy center for management, regardless of age and gender. Patients with no histological diagnosis were not included in this study.

The data was collected from the patient's medical records and the radiotherapy department's registry.

The parameters studied were: age, sex, family history of breast cancer, menopausal status, parity, breast tumor location, histological type, histological grade, stage of classification of the breast. Cancer.

The classification of cancers was based on the clinical examination according to the location of the primitive and on the extension assessment.

The clinical examination specified if possible the size of the tumor as well as its extensions. The radiological examinations were most often a mammography coupled with an ultrasound, a chest x-ray, an abdominopelvic ultrasound and/or a thoraco-abdominopelvic CT scan. Bone scans were not requested because they were not feasible in Mali. The search for hormonal receptors and the Her 2 neu membrane receptor by immunohistochemistry was also not feasible in Mali during the study period. The seventh edition of the TNM classification of the International Union against Cancer (UICC) was used for staging [6]. Data analysis was done using SPSS23.0 software. 


\section{Results}

Epidemiological characteristics:

From April 2014 to December 2016, we received 890 cases of cancer including 134 cases of breast cancer, a frequency of $15 \%$. With only one man the sex ratio $(\mathrm{H} / \mathrm{F})$ was 0.007 . The mean age of our patients was $47 \pm 11$ years with extremes ranging from 18 to 88 years. The most represented age groups were 33 - 47 years old with $45.5 \%$ and 48 - 62 years old with $38.8 \%$ (Table 1 ).

Clinical features:

In the cohort, $3 \%$ of patients had a family history of breast cancer. They were pauciparous in 59\%, multiparous in $32 \%$ of cases and nulliparous in $8 \%$ of cases. At the time of diagnosis, $50 \%$ of the patients were menopausal.

The clinical sign of discovery was a mammary nodule in $98 \%$ of patients. Mastodynia was found in $65 \%$ of patients. In $67 \%$, lymph node involvement was the mode of revelation. Nipple discharge was present in $18 \%$, the appearance of orange peel was found in $4 \%$ and ulceration in $16 \%$ (Table 2).

Paraclinical aspects:

Ultrasound was performed in all patients. It was coupled with mammography in $94 \%$ of cases.

Table 1. Characteristics of the study population.

\begin{tabular}{|c|c|c|}
\hline Characteristics & EFFECTIVE $(\mathrm{N}=134)$ & PERCENTAGE \% \\
\hline \multicolumn{3}{|l|}{ AGE } \\
\hline Mean & $47 \pm 11$ years & \\
\hline Médian & 47 years & \\
\hline Extreme & {$[18-88]$ years } & \\
\hline \multicolumn{3}{|l|}{ AGE GROUPS } \\
\hline 18 - 32 years & 10 & 7.5 \\
\hline $33-47$ years & 61 & 45.5 \\
\hline $48-62$ years & 52 & 38.8 \\
\hline $63-77$ years & 10 & 7.5 \\
\hline 78 - 92 years & 1 & 0.7 \\
\hline \multicolumn{3}{|c|}{ FAMILY ANTECEDENT OF BREAST CANCER } \\
\hline NO & 130 & 97.0 \\
\hline YES & 4 & 3.0 \\
\hline \multicolumn{3}{|l|}{ PARITY } \\
\hline Multiparous & 43 & 32.1 \\
\hline Not applicable & 1 & 0.7 \\
\hline Nulliparous & 11 & 8.2 \\
\hline Paucipare & 79 & 59.0 \\
\hline \multicolumn{3}{|l|}{ MENOPAUSE } \\
\hline No & 65 & 48.5 \\
\hline Yes & 68 & 50.7 \\
\hline
\end{tabular}


Table 2. Characteristics of the study population.

\begin{tabular}{|c|c|c|}
\hline Characteristics & $\begin{array}{l}\text { EFFECTIVE } \\
(\mathrm{N}=134)\end{array}$ & PERCENTAGE \% \\
\hline \multicolumn{3}{|c|}{ LOCATION OF CANCER } \\
\hline Bilatéral Breast & 2 & 1.5 \\
\hline Right breast & 52 & 38.8 \\
\hline Left breast & 80 & 59.7 \\
\hline \multicolumn{3}{|c|}{ CIRCUMSTANCES OF DISCOVERIES } \\
\hline \multicolumn{3}{|l|}{ NODULE } \\
\hline No & 2 & 1.5 \\
\hline Yes & 132 & 98.5 \\
\hline \multicolumn{3}{|l|}{ Mastodynia } \\
\hline No & 47 & 35.1 \\
\hline Yes & 87 & 64.9 \\
\hline \multicolumn{3}{|c|}{ AXILLARY ADENOPATHY } \\
\hline No & 44 & 32.8 \\
\hline Yes & 90 & 67.2 \\
\hline \multicolumn{3}{|c|}{ MAMELONARY FLOW } \\
\hline No & 109 & 81.3 \\
\hline Yes & 25 & 18.7 \\
\hline \multicolumn{3}{|l|}{ ORANGE PEEL } \\
\hline No & 129 & 96.3 \\
\hline Yes & 5 & 3.7 \\
\hline \multicolumn{3}{|l|}{ ULCERATION } \\
\hline No & 112 & 83.6 \\
\hline Yes & 22 & 16.4 \\
\hline \multicolumn{3}{|c|}{ HISTOLOGICAL TYPE } \\
\hline $\mathrm{CCI}$ & 126 & 94 \\
\hline CLI & 5 & 3.7 \\
\hline CMI & 2 & 1.5 \\
\hline Phyllode sarcoma & 1 & 0.7 \\
\hline \multicolumn{3}{|c|}{ GRADING SCARFF BLOOM OF RICHARDSON } \\
\hline \multicolumn{3}{|l|}{$(\mathrm{SBR})$} \\
\hline SBR I & 6 & 4.47 \\
\hline SBR II & 50 & 37.31 \\
\hline SBR III & 31 & 23.13 \\
\hline Unspecified & 47 & 35 \\
\hline
\end{tabular}

Histologically, infiltrating ductal carcinoma was found in $94 \%$ of patients. It was followed by infiltrating lobular carcinomas $(3.7 \%)$ and metaplastic carcinomas with $1.7 \%$. Sarcomas were found in $0.7 \%$ of cases. The rank of Scarff Bloom and Richardson (SBR), could be evaluated in $65 \%$ of which $4 \%$ of Grade I, $37 \%$ of Grade II and 23\% of Grade III.

As part of the extension assessment, $76 \%$ of patients had chest X-rays and $99 \%$ had abdominal ultrasonography. Thoracoabdominopelvic CT was performed in $60 \%$ of patients (Table 3 ). 
Table 3. Characteristics of the study population.

\begin{tabular}{|c|c|c|}
\hline Characteristics & $\begin{array}{l}\text { EFFECTIVE } \\
(\mathrm{N}=134)\end{array}$ & PERCENTAGE \% \\
\hline \multicolumn{3}{|c|}{ PARACLINIC EXAMINATIONS } \\
\hline \multicolumn{3}{|c|}{ MAMMOGRAPHY } \\
\hline No & 8 & 6.0 \\
\hline Yes & 126 & 94.0 \\
\hline \multicolumn{3}{|c|}{ BREAST ULTRASOUND } \\
\hline No & 0 & 0 \\
\hline Yes & 134 & 100.0 \\
\hline \multicolumn{3}{|l|}{ X-Ray Chest } \\
\hline No & 32 & 23.9 \\
\hline Yes & 102 & 76.1 \\
\hline \multicolumn{3}{|c|}{ ABDOMINAL ULTRASOUND } \\
\hline No & 1 & 0.7 \\
\hline Yes & 133 & 99,3 \\
\hline \multicolumn{3}{|c|}{ SCANNER THORACO-ABDOMINO \pm PELVIAN } \\
\hline No & 54 & 40.3 \\
\hline Yes & 80 & 59.7 \\
\hline \multicolumn{3}{|c|}{ SIZE OF TUMOR } \\
\hline Average & \multicolumn{2}{|l|}{$86.85 \pm 42.839 \mathrm{~mm}$} \\
\hline Median & \multicolumn{2}{|l|}{$93 \mathrm{~mm}$} \\
\hline extremes & \multicolumn{2}{|l|}{$[6-182] \mathrm{mm}$} \\
\hline \multicolumn{3}{|c|}{ CLASSIFICATION TNM UICC $7^{\text {th }}$ EDITION } \\
\hline \multicolumn{3}{|l|}{ TUMOR } \\
\hline $\mathrm{T} 1$ & 6 & 4.5 \\
\hline $\mathrm{T} 2$ & 23 & 17.2 \\
\hline T3 & 42 & 31.3 \\
\hline $\mathrm{T} 4$ & 63 & 47.0 \\
\hline \multicolumn{3}{|l|}{ ADENOPATHY } \\
\hline No & 43 & 32.1 \\
\hline N1 & 51 & 38.1 \\
\hline N2 & 24 & 17.9 \\
\hline N3 & 16 & 11.9 \\
\hline \multicolumn{3}{|l|}{ METASTASIS } \\
\hline M0 & 131 & 97.8 \\
\hline M1 & 3 & 2.2 \\
\hline \multicolumn{3}{|l|}{ STADING } \\
\hline IA & 3 & 2.2 \\
\hline IIA & 23 & 17.2 \\
\hline IIB & 9 & 6.7 \\
\hline IIIA & 29 & 21.6 \\
\hline IIIB & 52 & 38.8 \\
\hline IIIC & 15 & 11.2 \\
\hline IV & 3 & 2.2 \\
\hline
\end{tabular}

Mean tumor size was $87 \pm 43 \mathrm{~mm}$ with extremes ranging from 6 to $182 \mathrm{~mm}$. Patients were graded and staged according to the criteria of the seventh edition of the TNM classification of the International Union against Cancer (UICC). 
Thirty-one (31\%) of the patients had a tumor size greater than $5 \mathrm{~cm}$. In $47 \%$ of cases, the tumor was extended to the chest wall and/or the skin. The ipsilateral axillary lymphadenopathies were found in $38 \%$ of patients, while $18 \%$ had fixed homolateral axillary adenopathies and $12 \%$ had supraclavicular lymphadenopathies. Three percent of the patients had secondary locations. Stage III was predominantly represented with $72 \%$, followed by stage II with $24 \%$ and stages I and IV with $2 \%$ each (Table 3 ).

\section{Discussion}

Breast cancer is the first cancer in the world [1] [2]. In 33 months, at the Radiotherapy Center of the Mali Hospital, we collected 134 cases out of 890 cases of cancer (15\%), an average of 30.25 cases per year. In Africa the incidence of breast cancer varies between countries. So in Niger, Zaki et al. report 64.5 cases per year [7], in Togo, Darré et al., Report 22.5 cases per year [8]. Overall this frequency found in Africa is lower than in Europe and represents 24.2\% [1].

In our study, women accounted for $99.2 \%$ of cases, a sex ratio (M/F) of 0.007 . This result is lower than those reported in Niger and Togo which were respectively 0.03 and 0.023 [7] [8]. This could be explained by the fact that our study was monocentric. For some authors, the rarity of breast tumors in the male sex is explained by the atrophic nature of the gland, the delicacy of the milk ducts, the absence of acini and the abundance of fibrous tissue in man [9].

As for age, the extremes ranges from 18 and 88 years old, with an average age of $47 \pm 11$ years. These results are comparable to those found in Cameroon [4]. In our series, breast cancer was common in both patients before and after 50 years. The most represented age groups were respectively $33-47$ years old with $45.5 \%$ and 48 - 62 years old with $39 \%$ while in the Cameroonian series $17 \%$ of the patients were between 45 - 49 years old [4]. In Niger, Zaki et al. found $69.89 \%$ of breast cancers in women before age 50 [7]. The results found in Africa are different from those found in the USA or 50\% of cases of breast cancer are diagnosed in women over 65 years. In Europe, the incidence of breast cancer is 210 per 100,000 for women aged 50 - 54 and more than 300 per 100,000 women at age 70 [10] [11].

In our family history study, so-called hereditary breast cancer is rare with a frequency of $3 \%$. This result is significantly lower than the Cameroonian and Tunisian studies, which had recovered respectively $23 \%$ and $13.23 \%$ [12].

Conventionally, multiparity is a factor in reducing the risk of breast cancer, in our series, $32 \%$ of patients were multiparous. This result is lower than that of Sano et al. (7) with 54\% multiparas among women with breast cancer in Burkina Faso [13]. Breast cancer was diagnosed in $48.5 \%$ of premenopausal patients, which is lower than the study by Dem et al. Who found that $57.3 \%$ of these malignancies are diagnosed before age 50 [14].

The tumoral involvement concerned the left breast in $60 \%$ of cases, comparable to the Guinean series which found a frequency of $56 \%$ [15]. In $1.5 \%$ of cases 
the involvement was bilateral, in the literature the bilateral involvement varies between $3 \%-13 \%$ [16]. Regarding the circumstances of discovery, the self-examination of nodules was found in $98 \%$ of patients, which may or may not be associated with mammalian mastodynia and axillary adenopathy in more than $60 \%$ of cases, whereas in the Tunisian series, the nodule was present. at $81.4 \%$ [17].

Histologically, there was a preponderance of infiltrating ductal carcinomas with $94 \%$, followed by infiltrating lobular carcinoma with $3.7 \%$ and metaplastic carcinoma with $1.7 \%$. These results are comparable to the Moroccan and Cameroonian series but with different proportions [4] [18].

There was a predominance of SBR grade II in our patients, which corroborates with the Cameroonian study which also found a higher frequency of grade II SBR (66\%), followed by Grades III and I with $20 \%$ and $14 \%$ [4]. However it should be noted that $35 \%$ of our patients had not been able to benefit from this grading. Immunohistochemistry was not practiced during the study period; no patient was able to benefit from a search for hormonal receptors and Her2neu.

In our series, the average tumor size was $87 \mathrm{~mm}$, much higher than the patients of the Moroccan series which was $36 \mathrm{~mm}$, this could be explained by a lack of awareness and screening on breast cancer in Mali.

Stages II and III were predominantly represented with $24 \%$ and $72 \%$, thus requiring much more radical treatments. Bouchbika $\mathrm{Z}$ et al:; had demonstrated the value of early diagnosis and mammography screening, which increased from 2004-2009 to Ibn Rochd Hospital in Casablanca, stages II and III from 50\% and $30 \%$ to $54 \%$ and $16 \%$; which makes it possible to increase the rate of conservative treatments [3].

Our results concern the only cancer treatment center by radiotherapy in Mali, but are comparable to those of the Bamako cancer registry.

\section{Conclusion}

In our context breast cancer remains a major public health problem; in our series, we find a slight predominance of subjects under 50 years. The diagnosis is usually late in our context, hence it is the importance of raising awareness and screening before the age of 50 . This will promote more conservative and targeted treatments that will improve patient survival.

\section{Conflicts of Interest}

The authors declare no conflicts of interest regarding the publication of this paper.

\section{References}

[1] Bray, F., Ferlay, J., Soerjomataram, I., Siegel, R.L., Torre, L.A. and Jemal, A. (2018) Global Cancer Statistics 2018: GLOBOCAN Estimates of Incidence and Mortality Worldwide for 36 Cancers in 185 Countries. CA: A Cancer Journal for Clinicians, 68, 394-424. https://doi.org/10.3322/caac.21492 
[2] Youlden, D.R., Cramb, S.M., Dunn, N.A., et al. (2012). The Descriptive Epidemiology of Female Breast Cancer: An International Comparison of Screening, Incidence, Survival and Mortality. Cancer Epidemiology, 36, 237-248.

https://doi.org/10.1016/j.canep.2012.02.007

[3] Bouchbika, Z., Serhier, Z., Sahraoui, S., Bennani-Othmani, M. and Benider, A. (2012) Stade du cancer du sein lors du diagnostic: Impact des campagnes de sensibilisation. Pratiques et Organisation des Soins, 43, 269-275. https://doi.org/10.3917/pos.434.0269

[4] Ndamba Engbang, J.P., Essome, H., Mve Koh, V., Simo, G., Sime Essam, J.D., Sone Mouelle, A. and Oyono Essame, J.L. (2015) Cancer du sein au Cameroun, profil histo-épidémiologique: À propos de 3044 cas. The Pan African Medical Journal, 21, 242. https://doi.org/10.11604/pamj.2015.21.242.7269

[5] Traore, C.B., Coulibaly, B., Malle, B., Kamate, B., et al. (2012) Le cancer a bamako de 2006 a 2010. Données du registre des cancers au Mali. Revue Africaine de Pathologie Juin, 11.

[6] Sobin, L., et al. (2009) Classification TNM $7^{\text {ième }}$ édition de l'Union Internationale Contre le Cancer (UICC).

[7] Zaki, H.M., Garba-Bouda, O., Garba, S.M. and Nouhou, H. (2013) Profil épidémiologique et anatomopathologique du cancer du sein au Niger. African Journal of Cancer, 5, 185-191. https://doi.org/10.1007/s12558-013-0274-9

[8] Darré, T., Amegbor, K., Sonhayé, L., Kouyate, M., Aboubarak, A., N’Timo, B., et al. (2013) Profil histo-épidémiologique des cancers du sein: À propos de 450 cas observés au CHU de Lomé. Médecine d' Afrique Noire Électronique, 60, 53-58.

[9] Ioanmidou, L., Mouzakal, N.J., Agnantis, H. and Mahera, N.X. (1987) Papacharacampous. Journal de Gynécologie Obstétrique et Biologie de la Reproduction, 16, 851-860.

[10] Robert, J. and Kenn, M.C. (1994) Clinical Aspect of Cancer in the Elderly. Cancer, 74, 2107-2117.

[11] Naik, A.M., Joseph, K., Harris, M., Davis, C., Shapiro, R. and Hiotis, K.L. (2003) Indigent Breast Cancer Patients among All Racial and Ethnic Groups Present with More Advanced Disease Compared with Nationally Reported Data. The American Journal of Surgery, 186, 400-403. https://doi.org/10.1016/S0002-9610(03)00282-4

[12] Eisinger, F. (2005) Le dépistage des cancers du sein chez la femme à haut risque familial. Bulletin du Cancer, 92, 874-884.

[13] Sano, D.I., Cisse, R., Dao, B., Lankoande, J., Traore, S.S.L., Soudre, R.B., et al. (1998) Le cancer du sein: Problèmes diagnostiques et thérapêutiques au CHU de Ouagadougou. Médecine d'Afrique Noire, 45, 297-301.

[14] Dem, A., Traoré, B., Dieng, M.M., et al. (2006) Cancers gynécologiques et mammaires à l'Institut Curie de Dakar (Sénégal). Oncol Clin Afr, 2, 17-21.

[15] Diallo, M.S., Diallo, T.S., Diallo, S.B., Camara, N.D., Diallo, F.B., Dieng, A., Diallo, Y. and Diaw, S.T. (1996) Les tumeurs du sein: Épidémiologie, clinique, anatomie pathologique et pronostic. Médecine d Afrique Noire, 43.

[16] Cucinotta, E., Calbo, L., Palmeri, R., Pergolizzi, F.P. and Melita, G. (1996) Bilateral Carcinoma of the Breast. Chirurgia italiana, 49, 914.

[17] Jihen, J., Habib, A., Nabil, T., et al. (2010) Le cancer du sein chez la femme âgée epidémiologie et caractéristiques cliniques. JIM Sfax, No. 19/20, 36-46.

[18] Abbass, F., Bennis, S., Znati, K., Akasbi, Y., Amrani, J.K., El Mesbahi, O. and Amarti, A. (2011) Le profil épidémiologique et biologique du cancer du sein à Fès-Boulemane (Maroc). Eastern Mediterranean Health Journal, 17. 